\title{
The international wealth channel: a global error-correcting analysis
}

\author{
Nils Holinski · Robert Vermeulen
}

Received: 17 August 2010 / Accepted: 19 July 2011 / Published online: 9 September 2011

(C) The Author(s) 2011. This article is published with open access at Springerlink.com

\begin{abstract}
This article investigates empirically whether shocks to asset prices transmit into the trade balance through consumption and investment for a group of five of the world's most industrialized countries. We refer to this transmission channel as the international wealth channel and estimate a GVAR model including 29 countries with quarterly data over the period 1981Q1-2006Q4. Generalized impulse response functions show that after a negative stock price shock US and UK consumption decreases, followed by an improving trade balance. This pattern is also visible for France, but not for Germany and Japan. Stock price decreases are only associated with decreasing investment and an improving trade balance in the UK. For housing, we do find that a negative shock to UK housing prices decreases domestic investment and improves the trade balance. However, this pattern is not visible in the other countries. Finally, a domestic negative real exchange rate shock only has a significantly positive impact on the US trade balance.
\end{abstract}

Keywords Trade balance · Wealth effect · Global imbalances · GVAR · International transmission

JEL Classification $\quad \mathrm{E} 21 \cdot \mathrm{F} 15 \cdot \mathrm{F} 41 \cdot \mathrm{G} 15$

\footnotetext{
N. Holinski

Department of Economics, Maastricht University, P.O. Box 616, 6200 MD Maastricht, The Netherlands

R. Vermeulen $(\varangle)$

Economics and Research Division, De Nederlandsche Bank, P.O. Box 98,1000 AB Amsterdam, The Netherlands

e-mail: r.j.g.vermeulen@dnb.nl
} 


\section{Introduction}

Over the past two decades, global trade imbalances increased sharply, characterized by large US trade deficits and large trade surpluses for other countries, such as China and Japan. Several causes and solutions have been put forward to explain these imbalances, e.g., necessary exchange rate adjustments (Blanchard et al. 2005) or relative output growth rates due to productivity differentials (Bems et al. 2007; Corsetti et al. 2008). Caballero et al. (2008) argue that the US is the main destination for savings of Asian and oil producing economies, since the US has the capacity to produce financial assets, thereby creating US trade deficits. However, the role of asset prices has received relatively little attention, even though assets such as stocks and housing property constitute the bulk of household wealth. Fratzscher et al. (2010) investigate the relative importance of stock market and housing prices for the US current account. ${ }^{1}$ Their results show that asset price changes are at least as important as exchange rate movements for the US current account balance.

While Fratzscher et al. (2010) investigate the effect of asset price changes on the current account, this article investigates explicitly how the asset price shocks are transmitted via consumption or investment decisions to the trade balance. We refer to this channel as the international wealth channel. Its existence is investigated for a group of five of the world's most industrialized economies (G5) - the US, UK, France, Germany, and Japan. We are particularly interested in studying the relative strength of the international wealth channel and test whether or not it can emerge as a potent alternative to the traditional exchange rate channel in correcting global trade imbalances.

We empirically analyze the international wealth channel using the GVAR model, first introduced by Pesaran et al. (2004) — hereafter PSW — and advanced in Dees et al. (2007). We include 29 countries with data at quarterly frequency over the time period 1981Q1-2006Q4. The country sample covers all countries and regions that figure prominently in the current debate on global imbalances-US, China, Europe, Asia, and oil-exporting countries. The most important reason for ending the sample period in 2006 is the outbreak of the financial crisis in 2007. While the GVAR can accommodate so called "co-breaking", the changes during 2007-2010 are so dramatic that the model will not work properly. In particular, estimated relationships between variables will change. However, a full fledged modeling of the financial crisis using a model better suitable to capture the financial crisis is beyond the scope of this article. Hence, we focus on the pre-crisis wealth channel and how it operates under tranquil times.

An important advantage of the GVAR model, compared to the Bayesian VAR model of Fratzscher et al. (2010), is that we model the developments in foreign countries explicitly, instead of leaving the rest of the world unmodeled. Considering, for instance, a shock to US asset markets, our estimation strategy allows for the possibility that the shock translates into the asset markets, and subsequently consumption and investment decisions, of the other 28 countries from where it potentially feeds back into the US trade balance.

\footnotetext{
${ }^{1}$ See Fratzscher and Straub (2009) for a multi-country application.
} 
The article investigates the effect of three specific negative shocks on consumption/investment and the trade balance using generalized impulse response functions: (1) exchange rate, (2) stock price, and (3) housing price. Overall, the empirical results do not show a homogenous picture across countries and we need to conclude that the international wealth channel is an important determinant of trade balance movements in some countries, but not all.

A domestic real exchange rate depreciation only has a significant positive impact on the US trade balance. It is surprising that this negative real exchange rate shock has a negligible effect on the trade balance of Germany and Japan, which are strong export-oriented economies.

There is evidence for the presence of the international wealth channel after a domestic stock price shock. For the US and UK consumption decreases significantly after the shock, followed by an improving trade balance in both countries. This pattern is also visible for France, but not for Germany and Japan. When investigating the international wealth channel with investment in the model, we only find evidence for its presence in the UK.

Finally, the housing price shock does not show evidence of the international wealth channel through consumption. Even though the US trade balance improves, the shock is not transmitted through US consumption. When investigating the transmission through investment, we do find that a negative shock to UK housing prices decreases domestic investment and improves the trade balance. However, this pattern is not visible in any of the other countries.

The rest of the article is organized as follows. Section 2 discusses the theory on the international wealth channel. Next, Sect. 3 sets out the empirical setup and the data series that we have used. Section 4 presents the impulse response functions, and Sect. 5 discusses the forecast error variance decomposition. Finally, Sect. 6 concludes.

\section{The international wealth channel}

The international wealth channel is the process where asset price changes are transmitted to the trade balance through consumption and investment decisions by households and firms. Wealth changes do not only impact the demand for domestically produced goods and services in an open economy, but will also change the demand for imported goods and services. Fratzscher et al. (2010) and Fratzscher and Straub (2009) show that stock and housing price shocks have a significant impact on the trade balance mainly for the US, whereas the reaction of other countries differs. This article focuses explicitly on the transmission channel. When investigating these shocks we signal out two transmission channels: (1) asset prices $\rightarrow$ consumption $\rightarrow$ trade balance and (2) asset prices $\rightarrow$ investment $\rightarrow$ trade balance.

First, consider the theoretical motivation of the consumption channel. The permanent income hypothesis predicts that private consumption increases in response to household wealth increases (Modigliani and Brumberg 1954; Friedman 1957). Many authors find empirical evidence that stock and housing price increases have a significantly positive effect on consumption (Ludvigson and Steindel 1999; 
Lettau and Ludvigson 2001, 2004; Case et al. 2005; Palumbo et al. 2006). This holds not only for the US, but for a large number of countries.

In an open economy model, Caballero et al. (2008) link wealth changes to the trade balance via consumption. Basically, wealth is explicitly incorporated in the consumption function and, by construction, the trade balance is domestic production minus consumption and thus depends directly on wealth changes. On the other hand, Laibson and Mollerstrom (2010) provide an alternative theoretical model connecting asset price bubbles, with increasing consumption and worsening trade balances. Fratzscher and Straub (2009) provide empirical evidence for the existence of this channel for the US, Germany, and France. However, they do not find it to be present for the UK, Italy, Japan, and Canada.

The second channel through which asset prices transmit to the trade balance of a country are business and private expenditures on investments. The theoretical roots of this alternative are based on Tobin's $q$-theory of business investment (Tobin 1969). It posits that firms find it attractive to invest in their capital stock in bullish asset markets as the ratio between the market value and the replacement value of its capital stock increases (Barro 1990). The same reasoning applies to housing investment. Basically, when the prices of houses increase, it is attractive to build new houses and devote resources to the construction sector (Green et al. 2005). Running a trade deficit allows the financing of these housing investments (Punzi 2008).

\section{Methodology}

In this section, we first motivate the variables included in the country-individual models and discuss data considerations. Next, we briefly outline the GVAR methodology and address a number of issues surrounding the proper fitting of the models to the data generating process. ${ }^{2}$

\subsection{Variable selection and data considerations}

The inclusion of variables in the country-individual models is guided by simple aggregate demand functions of open economy models and our focus on the international wealth channel (Obstfeld and Rogoff 1996; Sørensen and Whitta-Jacobsen 2005). We consider two separate models to investigate the role of consumption and investment in the transmission of asset shocks. Consider first the $k_{i} \times 1$ vector of endogenous variables with consumption included

$$
\mathbf{y}_{i t}=\left[\begin{array}{lllllllll}
\mathrm{tb}_{i t} & \mathrm{rc}_{i t} & \mathrm{ry}_{i t} & \operatorname{reer}_{i t} & \mathrm{rs}_{i t} & \mathrm{rh}_{i t} & r_{i t}^{\mathrm{s}} & r_{i t}^{1} & p_{i t}^{\mathrm{oil}}
\end{array}\right]^{\prime 3}
$$

\footnotetext{
${ }^{2}$ For a full exposition of the GVAR methodology, we refer the interested reader to Pesaran et al. (2004) and Dees et al. (2007).

${ }^{3}$ Depending on the availability of data, we include fewer variables in some country models. See the Appendix for data availability and sources.
} 
for country-individual VECM, $i$. Note that the ordering of the variables is not important since we use generalized impulse response functions in the empirical analysis.

The trade balance $\left(\mathrm{tb}_{i t}\right)$ is defined as the log of exports over imports; real consumption $\left(\mathrm{rc}_{i t}\right)$ is the log of household consumption; real gross domestic product $\left(\mathrm{ry}_{i t}\right)$ is the log of gdp; the real effective exchange rate $\left(\operatorname{reer}_{i t}\right)$ is expressed in logs; real stock market prices $\left(\mathrm{rs}_{i t}\right)$ are the log of a broad stock market index and real housing prices $\left(\mathrm{rh}_{i t}\right)$ are the log of a housing price index. We capture the short term real interest rate $\left(r_{i t}^{\mathrm{s}}\right)$ using the three-month money market rate and the real long term interest rate $\left(r_{i t}^{1}\right)$ as the rate on 10-year government bonds. Both interest rates are calculated by $r_{i t}^{\mathrm{q}}=\ln \left(1+R_{i t}^{\mathrm{q}} / 100\right)$, where $R_{i, t}^{\mathrm{q}}$ is the short or long term real interest rate. All variables except $\mathrm{tb}_{i t}$ and reer $_{i t}$ are deflated by the consumer price index to express these in real terms.

The nominal log oil price ( $p_{i t}^{\text {oil }}$ ) controls for global political events as an observable common factor to all countries. Despite the growing importance of emerging economies, most notably China, we follow Dees et al. (2007) and include $p_{i t}^{\text {oil }}$ as an endogenous variable only in the US model, while retaining it as weakly exogenous in all other country models. A weak exogeneity test supports this choice. Table 1 summarizes the availability of variables across countries.

To analyze the transmission through investment behavior we replace real consumption with real investment $\left(\mathrm{ri}_{i t}\right)$ in Eq. 1:

$$
\mathbf{y}_{i t}=\left[\begin{array}{lllllllll}
\mathrm{tb}_{i t} & \mathrm{ri}_{i t} & \mathrm{ry}_{i t} & \operatorname{reer}_{i t} & \mathrm{rs}_{i t} & \mathrm{rh}_{i t} & r_{i t}^{\mathrm{s}} & r_{i t}^{1} & p_{i t}^{\mathrm{oil}}
\end{array}\right]^{\prime} .
$$

In both models, we include the trade balance instead of the current account, because our objective is to capture the consumption or investment induced demand for foreign goods and services. The current account also includes factor income received and paid, which should be relatively unaffected by e.g., a domestic increase in housing prices. Hence, the trade balance measures more closely the domestic and foreign demand for goods and services. Expressing the trade balance as the log of exports over imports brings this variable closer to a normal distribution, compared to expressing it as a percentage of gdp. This is an important consideration in a VAR which assumes normally distributed errors.

The real effective exchange rate captures the competitiveness of an economy, while movements in financial and non-financial household wealth are captured by $\mathrm{rs}_{i t}$ and $\mathrm{rh}_{i t}$, respectively. The use of price indices as proxies for household wealth can be viewed as a limitation of our analysis. Fortunately, studies by Ludwig and Sløk (2004) and Fratzscher et al. (2010) confirm that differences to volume-based proxies for wealth are immaterial in estimations. Moreover, price indices allow exploiting the quarterly frequency at which these data are available.

We include $r_{i t}^{\mathrm{s}}$ and $r_{i t}^{1}$ in the country models to capture the term structure of interest rates. Both interest rates are necessary to properly model the financial and real variables. For example, short term rates are important for exchange rates and stock market returns, while housing prices depend more on long term interest rates.

Consumption and investment are not modeled jointly for several reasons. First, we aim to investigate the international wealth channel for each of the two variables sep- 


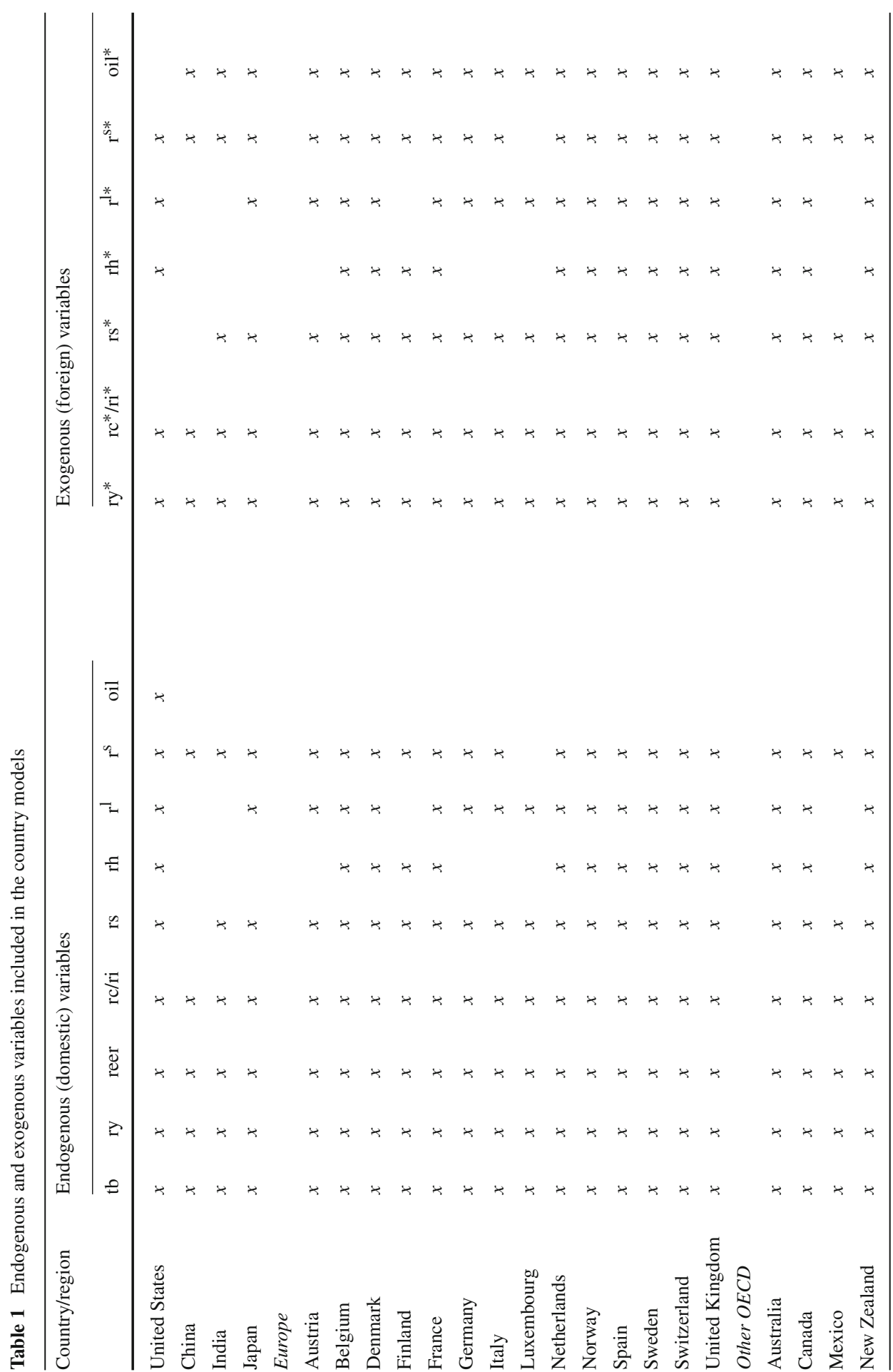




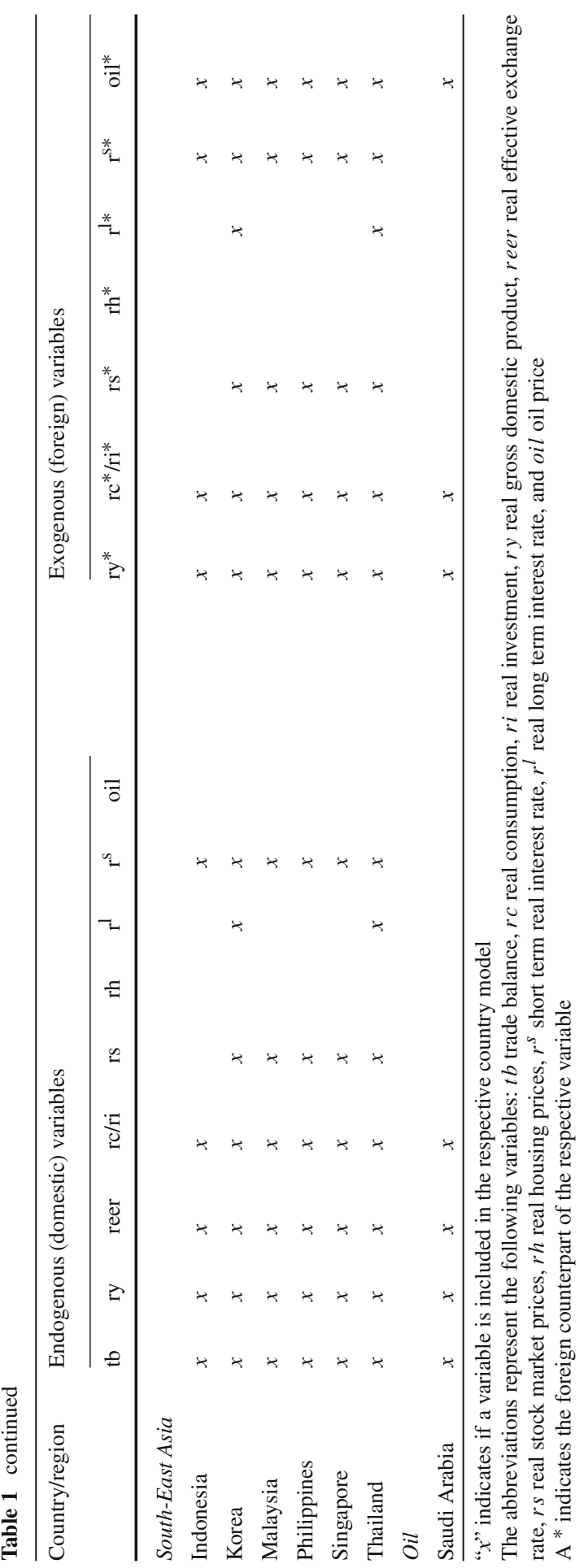


arately, i.e., we avoid a contemporaneous dependence of consumption on investment and vice versa. Second, further increasing the number of variables results in degree of freedom problems.

In order to link the individual country models and create international transmission channels, we match the domestic variables with trade-weighted foreign variables. The foreign variables remain unmodeled in the country models and thus need to satisfy weak exogeneity requirements for inference and impulse response analysis. We test and elaborate on the weak-exogeneity condition below. The $k_{i}^{*} \times 1$ vector of foreign variables is denoted by

$$
\mathbf{y}_{i t}^{*}=\left[\begin{array}{lllllll}
\mathrm{rc}_{i t}^{*} & \mathrm{ry}_{i t}^{*} & \mathrm{rs}_{i t}^{*} & \mathrm{rh}_{i t}^{*} & r_{i t}^{\mathrm{s}^{*}} & r_{i t}^{1^{*}} & p_{i t}^{\mathrm{oil}}
\end{array}\right]^{\prime}
$$

with consumption, and

$$
\mathbf{y}_{i t}^{*}=\left[\begin{array}{lllllll}
\mathrm{rr}_{i t}^{*} & \mathrm{ry}_{i t}^{*} & \mathrm{rs}_{i t}^{*} & \mathrm{rh}_{i t}^{*} & r_{i t}^{\mathrm{s}^{*}} & r_{i t}^{1^{*}} & p_{i t}^{\mathrm{oil}}
\end{array}\right]^{\prime}
$$

with investment included. The trade-weighted averages are calculated using the sum of bilateral exports and imports between country $i$ and $j$ relative to total exports and imports of country $i{ }^{4}$ We employ time-invariant trade-weights in the construction of foreign variables, which we obtain as averages over the years 2000-2004. Results show a large correlation between the foreign variables when using fixed or varying trade weights. This strong relationship is not spurious, because the correlation between the first differenced foreign variables is also very high, especially for financial data. Therefore, using time-invariant weights is not overly restrictive.

Obviously, the correct choice of the weights is key in creating the international transmission channels. The use of information on bilateral trade in goods and services seems to be the natural choice for our study on the international wealth channel. An alternative choice is information on bilateral capital flows. Unfortunately, data are not consistently available for all countries in our sample and we do not expect significant differences. In fact, several studies show that trade in goods and services are highly correlated with capital flows (Portes and Rey 2005; Lane and Milesi-Ferretti 2008). ${ }^{5}$

\subsection{Estimating the GVAR model}

The GVAR methodology of PSW and Dees et al. (2007) proceeds in two stages. The first stage is the estimation stage of the following reduced form augmented vector autoregression, $\operatorname{VARX}(p, q)$, model for each country $i$ in our sample, while in the second stage we stack all 29 individual country VARX models and link them using a weight matrix.

\footnotetext{
4 The complete trade weight matrix is available upon request. We adjust the trade-weights if data are not available for some countries and some variables.

5 Alternatively, one can consider using bilateral bank lending exposures instead of trade weights (Galesi and Sgherri 2009). Unfortunately, data availability is a problem. For example, lending exposures for China are missing and for other countries data for the timespan 1980-2006 is not fully available. Hence, for this study a weighting matrix based on trade weights is most attractive.
} 
In the first step, we model each country as a $\operatorname{VARX}(p, q)$

$$
\begin{gathered}
\mathbf{y}_{i t}=\boldsymbol{\delta}_{i 0}+\boldsymbol{\delta}_{i 1} t+\sum_{l=1}^{p} \boldsymbol{\Phi}_{i l} \mathbf{y}_{i, t-l}+\sum_{m=0}^{q} \boldsymbol{\Psi}_{i m} \mathbf{y}_{i, t-m}^{*}+\boldsymbol{\epsilon}_{i t}, \\
i=1,2, \ldots, N, \quad t=1,2, \ldots, T
\end{gathered}
$$

where $\boldsymbol{\delta}_{i 0}$ and $\boldsymbol{\delta}_{i 1}$ are $k_{i} \times 1$ coefficient vectors of the deterministic intercept and time trend. ${ }^{6} \mathbf{y}_{i t}$ is a $k_{i} \times 1$ vector of country-specific variables, as determined in Eq. 1 with consumption, Eq. 2 with investment and corresponding $k_{i} \times k_{i}$ matrices of lagged coefficients, denoted by $\boldsymbol{\Phi}_{i l} . \mathbf{y}_{i t}^{*}$ is a $k_{i}^{*} \times 1$ vector of trade-weighted foreign variables, as determined in Eq. 3 with consumption, Eq. 4 with investment and corresponding $k_{i} \times k_{i}^{*}$ matrices of contemporaneous and lagged coefficients, denoted by $\boldsymbol{\Psi}_{i m} . \boldsymbol{\epsilon}_{i t}$ is a $k_{i} \times 1$ vector of zero mean, idiosyncratic country-specific shocks, assumed to be serially uncorrelated with a time invariant covariance matrix $\Sigma_{i i}$.

The weak exogeneity assumption of $\mathbf{y}_{i t}^{*}$ rules out long run feedbacks from $\mathbf{y}_{i t}$ to $\mathbf{y}_{i t}^{*}$. However, we do allow for short run feedbacks between $\mathbf{y}_{i t}$ and $\mathbf{y}_{i t}^{*}$. Next, we determine the order of the dynamic specification according to the Akaike information criterion (AIC). We allow at maximum for a $\operatorname{VARX}(2,1)$ specification to reduce the number of estimated parameters and avoid degrees of freedom problems. The lag orders of the individual countries are reported in Table 2.

In the second stage of the GVAR methodology, we cast the country-specific models into their global representation. First, we determine the number of long-run cointegrating vectors according to the trace test statistic (Table 2) and rewrite (5) in its error-correction form

$$
\mathbf{A}_{i} \Delta \mathbf{z}_{i t}=\boldsymbol{\delta}_{i 0}+\boldsymbol{\delta}_{i 1} t-\left(\mathbf{A}_{i}-\mathbf{B}_{i}-\mathbf{C}_{i}\right) \mathbf{z}_{i, t-1}-\boldsymbol{\Phi}_{i 2} \Delta \mathbf{y}_{i, t-1}+\boldsymbol{\epsilon}_{i t},
$$

where $\mathbf{z}_{i t}=\left(\begin{array}{ll}\mathbf{y}_{i t} & \mathbf{y}_{i t}^{*}\end{array}\right)^{\prime}$. Next, we stack the endogenous variables of all individual country models in a $k \times 1$ global variable vector $\mathbf{y}_{t}=\left(\mathbf{y}_{1 t}, \mathbf{y}_{2 t} \ldots \mathbf{y}_{N t}\right)^{\prime}$ with $k=\sum_{i=1}^{N} k_{i}$ and solve for the global VECM representation

$$
\mathbf{F} \Delta \mathbf{y}_{t}=\boldsymbol{\delta}_{0}+\boldsymbol{\delta}_{1} t-(\mathbf{F}-\mathbf{G}-\mathbf{H}) \mathbf{y}_{t-1}+\boldsymbol{\Phi}_{2} \Delta \mathbf{y}_{t-1}+\boldsymbol{\epsilon}_{t}
$$

where

$$
\boldsymbol{\delta}_{0}=\left(\begin{array}{c}
\boldsymbol{\delta}_{10} \\
\boldsymbol{\delta}_{20} \\
\vdots \\
\boldsymbol{\delta}_{N 0}
\end{array}\right), \quad \boldsymbol{\delta}_{1}=\left(\begin{array}{c}
\boldsymbol{\delta}_{11} \\
\boldsymbol{\delta}_{21} \\
\vdots \\
\boldsymbol{\delta}_{N 1}
\end{array}\right), \quad \boldsymbol{\phi}_{2}=\left(\begin{array}{c}
\boldsymbol{\Phi}_{12} \\
\boldsymbol{\Phi}_{22} \\
\vdots \\
\boldsymbol{\Phi}_{N 2}
\end{array}\right), \quad \boldsymbol{\epsilon}_{t}=\left(\begin{array}{c}
\boldsymbol{\epsilon}_{1 t} \\
\boldsymbol{\epsilon}_{2 t} \\
\vdots \\
\boldsymbol{\epsilon}_{N t}
\end{array}\right)
$$

\footnotetext{
6 The estimations are based on the GAUSS code of Vanessa Smith.
} 
Table 2 VARX order and number of cointegrating relationships

\begin{tabular}{|c|c|c|c|c|c|c|}
\hline \multirow[t]{3}{*}{ Country/region } & \multicolumn{3}{|c|}{ Consumption model } & \multicolumn{3}{|c|}{ Investment model } \\
\hline & \multicolumn{2}{|c|}{$\operatorname{VARX}^{*}\left(\mathrm{p}_{i}, \mathrm{q}_{i}\right)$} & \multirow{2}{*}{$\begin{array}{l}\text { \# Cointegrating } \\
\text { relationships }\end{array}$} & \multicolumn{2}{|c|}{$\operatorname{VARX}^{*}\left(\mathrm{p}_{i}, \mathrm{q}_{i}\right)$} & \multirow{2}{*}{$\begin{array}{l}\text { \# Cointegrating } \\
\text { relationships }\end{array}$} \\
\hline & $\mathrm{p}_{i}$ & $\mathrm{q}_{i}$ & & $\mathrm{p}_{i}$ & $\mathrm{q}_{i}$ & \\
\hline United States & 2 & 1 & 3 & 2 & 1 & 3 \\
\hline China & 2 & 1 & 2 & 2 & 1 & 4 \\
\hline India & 2 & 1 & 1 & 2 & 1 & 1 \\
\hline Japan & 2 & 1 & 4 & 2 & 1 & 4 \\
\hline \multicolumn{7}{|l|}{ Europe } \\
\hline Austria & 2 & 1 & 4 & 2 & 1 & 6 \\
\hline Belgium & 2 & 1 & 5 & 2 & 1 & 6 \\
\hline Denmark & 2 & 1 & 5 & 1 & 1 & 5 \\
\hline Finland & 2 & 1 & 3 & 2 & 1 & 2 \\
\hline France & 2 & 1 & 3 & 2 & 1 & 4 \\
\hline Germany & 1 & 1 & 3 & 1 & 1 & 3 \\
\hline Italy & 2 & 1 & 3 & 1 & 1 & 3 \\
\hline Luxembourg & 2 & 1 & 3 & 2 & 1 & 2 \\
\hline Netherlands & 2 & 1 & 3 & 2 & 1 & 3 \\
\hline Norway & 2 & 1 & 4 & 2 & 1 & 4 \\
\hline Spain & 2 & 1 & 5 & 2 & 1 & 5 \\
\hline Sweden & 2 & 1 & 6 & 2 & 1 & 6 \\
\hline Switzerland & 2 & 1 & 4 & 1 & 1 & 6 \\
\hline United Kingdom & 2 & 1 & 3 & 2 & 1 & 3 \\
\hline \multicolumn{7}{|l|}{ Other OECD } \\
\hline Australia & 2 & 1 & 3 & 2 & 1 & 3 \\
\hline Canada & 2 & 1 & 4 & 1 & 1 & 5 \\
\hline Mexico & 2 & 1 & 3 & 2 & 1 & 3 \\
\hline New Zealand & 2 & 1 & 3 & 2 & 1 & 3 \\
\hline \multicolumn{7}{|l|}{ South-East Asia } \\
\hline Indonesia & 1 & 1 & 2 & 2 & 1 & 3 \\
\hline Korea & 2 & 1 & 4 & 2 & 1 & 5 \\
\hline Malaysia & 2 & 1 & 2 & 2 & 1 & 3 \\
\hline Philippines & 2 & 1 & 3 & 2 & 1 & 2 \\
\hline Singapore & 1 & 1 & 3 & 2 & 1 & 3 \\
\hline Thailand & 2 & 1 & 3 & 2 & 1 & 3 \\
\hline \multicolumn{7}{|l|}{ Oil } \\
\hline Saudi Arabia & 2 & 1 & 2 & 2 & 1 & 2 \\
\hline
\end{tabular}

VARX order determined by the AIC, with $p \leq 2$ and $q=1$, where $p$ is the number of endogenous lags and $q$ the number of exogenous lags 
and

$$
\mathbf{F}=\left(\begin{array}{c}
\mathbf{A}_{1} \mathbf{W}_{1} \\
\mathbf{A}_{2} \mathbf{W}_{2} \\
\vdots \\
\mathbf{A}_{N} \mathbf{W}_{N}
\end{array}\right), \quad \mathbf{G}=\left(\begin{array}{c}
\mathbf{B}_{1} \mathbf{W}_{1} \\
\mathbf{B}_{2} \mathbf{W}_{2} \\
\vdots \\
\mathbf{B}_{N} \mathbf{W}_{N}
\end{array}\right), \quad \mathbf{H}=\left(\begin{array}{c}
\mathbf{C}_{1} \mathbf{W}_{1} \\
\mathbf{C}_{2} \mathbf{W}_{2} \\
\vdots \\
\mathbf{C}_{N} \mathbf{W}_{N}
\end{array}\right)
$$

$\mathbf{W}_{i}$ is the link matrix that allows the country-individual models to be written in terms of the global variable vector, $\mathbf{y}_{t}$. The $\mathbf{W}_{i}$ s are country-specific $\left(k_{i}+k_{i}^{*}\right) \times k$ matrices of fixed constants defined by the trade-weights that were used above in the construction of the foreign variables. The global VECM of (7) allows for interaction among the included economies through three different but interrelated channels: (i) the contemporaneous dependence of domestic variables, $\mathbf{y}_{i t}$, on foreign variables, $\mathbf{y}_{i t}^{*}$, and on its lagged values, (ii) the dependence of all endogenous variables on common global exogenous variables (e.g., oil price), and (iii) the nonzero contemporaneous dependence of shocks in country $i$ on shocks in country $j$. Cross-country shocks are allowed to be weakly correlated in $\Sigma_{i j}$.

Note that in the global VECM representation, domestic variables are no longer contemporaneously dependent on foreign variables. This implies that we can solve the global model forward recursively, obtain future values of all endogenous variables and conduct impulse response analysis. Before doing so in Sect. 4, we first have a closer look at the statistical properties of the data series.

\subsection{Properties of the data series and specification tests}

This section summarizes the main characteristics of the data series and the results from several specification tests. An appendix containing detailed results is available from the authors upon request.

As a first step in specifying the country-individual model, we determine the integration properties of the included variables. The error-correction representation of the GVAR methodology assumes that the included variables are approximately integrated of order one. We follow PSW and base our unit root tests on weighted symmetric estimations of ADF type regressions. Real consumption, real output, real effective exchange rates, and real stock and oil prices are unambiguously I(1) processes for the vast majority of countries, or else $I(0) / I(1)$ borderline cases. The trade balances of our focus countries are unambiguously $I(1)$, while most others are $I(0)$. The real housing price series are $I(1)$ processes with four notable exceptions: US, Belgium, the Netherlands and Sweden. The last years of the sample period render the processes I(2). Finally, the hypothesis that interest rates are $I(1)$ is rejected for many countries and may result in an efficiency loss in estimation. Overall, however, it seems appropriate for our modeling strategy to treat all variables as approximately $I(1)$. The stability of the impulse responses below and the eigenvalues of the GVAR model lend credibility to this conclusion. ${ }^{7}$

\footnotetext{
7 The model with consumption appears to be more stable compared to the model with investment included.
} 
Having established the integration properties, we proceed with specifying the number of long run cointegrating relationships that exist between both domestic and foreign variables in each country model. In fact, empirical evidence suggest several long run relationships. For example, using US data Lettau and Ludvigson (2001) find a cointegrating vector between consumption, wealth and personal income. Case and Shiller (2003) and Black et al. (2006) document cointegrating relationships between housing prices, income, and interest rates. There is some evidence that international stock markets are cointegrated (Kasa 1992), but these results are challenged by Richards (1995). Meese and Rogoff (1988) investigate the cointegrating properties of real exchange rates and real interest rate differentials, but reject a stable relationship between both variables. On the other hand, Bergvall (2004) finds a single cointegrating relationship between the trade balance, exchange rates, relative gdp, and the real oil price for Scandinavian countries.

We allow the data to determine these cointegrating relationships and, based on the trace statistic, Table 2 reports the number of cointegrating relationships for each country model. The number ranges from 1 for India to 6 for Sweden and Switzerland, but for the great majority of countries, including our G5 countries, we find 3-4 cointegrating relationships. Note that there can be small differences between the consumption and investment models, even though the number of cointegrating relationships is identical for the majority of countries in both models.

Next, virtually all foreign variables $\mathbf{y}_{i t}^{*}$ pass the weak exogeneity test, which is a key assumption underlying our estimation strategy. However, we do find 8 out of 172 cases to be statistically significant at the 5\% nominal level. For our study, it is reassuring that for the set of focus countries, weak exogeneity can only be rejected for foreign real output in the Japanese country model, while all other foreign variables are weakly exogenous. ${ }^{8}$ Given the size and importance of the US equity market, we exclude foreign real stock prices from the US country model because weak exogeneity is violated.

Finally, the structural stability of long-run coefficients, short-run coefficients, and the error variances is an underlying assumption of the GVAR model. Dees et al. (2007) point out that structural stability problems are reduced with the inclusion of foreign variables in the country-individual models. In addition, the GVAR is able to accommodate the so-called "co-breaking", which should make it more robust to the possibility of structural breaks than reduced-form single-equation models. However, even though the GVAR can accommodate 'co-breaking' the GVAR is probably less suited to deal with crisis situations and to avoid stability problems we choose to exclude the current financial and economic crisis from the data.

Following Dees et al. (2007), we consider structural stability tests on the short-run coefficients and error variances. These findings suggest that the main reason for rejection by the tests appears to be breaks in error variances and not changes in the parameter coefficients. So, most of the structural parameters in our model seem to be relatively stable and concerns for structural breaks are mitigated. In line with Dees et al. (2007), we account for heteroskedasticity by using robust bootstrapped standard

\footnotetext{
8 As a robustness check, we excluded those foreign variables that do not pass the weak exogeneity test. The differences in estimation are immaterial.
} 
errors for the confidence bounds of the GIRFs and interpret the GIRFs conservatively by taking $90 \%$ confidence bounds. ${ }^{9}$

\section{Results}

The complex cross-border interdependencies that are an integral part of our global model are best summarized by investigating the dynamic response of the system to exogenous shocks in the error of a given variable. The analysis is carried out by making use of generalized impulse response functions (GIRF) which have been introduced by Koop et al. (1996) for non-linear systems and advanced by Pesaran and Shin (1998) for vector error-correcting systems. Unlike traditional orthogonalized impulse response functions, the GIRF neither requires imposing identification restrictions, nor is it variant to the ordering of the endogenous variables in the global vector, $\mathbf{y}_{t}$. Both are clearly important considerations in our model that considers a total of 204 endogenous variables in 29 country models. As there is no strong a priori belief on the exact ordering of these variables and countries, we do not aim to identify structural shocks. ${ }^{10}$

In fact, the GIRF does not allow for a structural interpretation of the impulseresponse results, but provides valuable information on the dynamics of the transmissions of shocks. When discussing the results of e.g., the consumption model it is important to stress that the VAR model allows investment to play a role, even though investment is not modeled explicitly. For example, investment plays a role through gdp or the error terms. Hence, when drawing conclusions regarding consumption in the consumption model, we infer conclusions regarding consumption, but are silent about investment. This holds vice versa for the investment model.

In what follows, we will investigate the time profiles and dynamic responses of domestic variables to a one standard error negative shock to (1) the real effective exchange rate, (2) domestic real stock prices and, if available, and (3) domestic real housing prices. In turn, we will focus mainly on whether trade balance movements can be attributed to consumption and investment changes. The figures show the bootstrapped median impulse responses for the first 20 quarters following the shock together with the associated 5 and $95 \%$ confidence bounds. To stay focused, we will concentrate on the G5 countries in the exposition of our results.

\subsection{Exchange rate shock}

Each of the G5 countries will be exposed to a domestic real exchange rate depreciation. First, we investigate the effects of this shock on consumption and the trade balance. Thereafter, we analyze the response of investment and the trade balance to the real exchange rate shock. Figure 1 presents the results for the first shock. The left column shows the median and $90 \%$ confidence bounds for the one standard deviation negative real effective exchange rate shock. Naturally, this shock is significantly negative for

\footnotetext{
9 The confidence bounds are obtained using the sieve bootstrap procedure analogous to Dees et al. (2007) with 2000 replications.

10 See e.g., Beaudry and Portier (2006) for a structural interpretation of stock price shocks.
} 

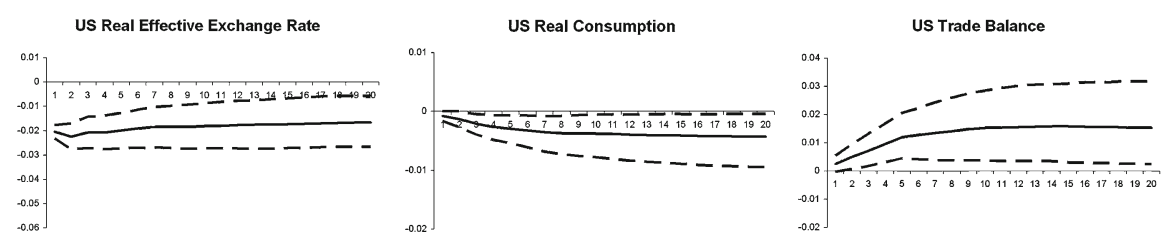

UK Real Effective Exchange Rate
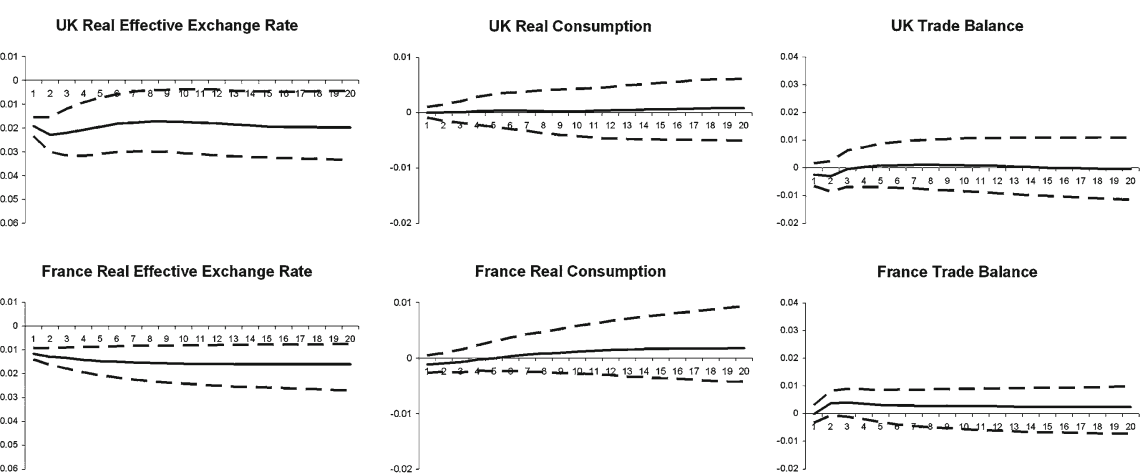

Germany Real Effective Exchange Rate

Germany Real Consumption

Germany Trade Balance
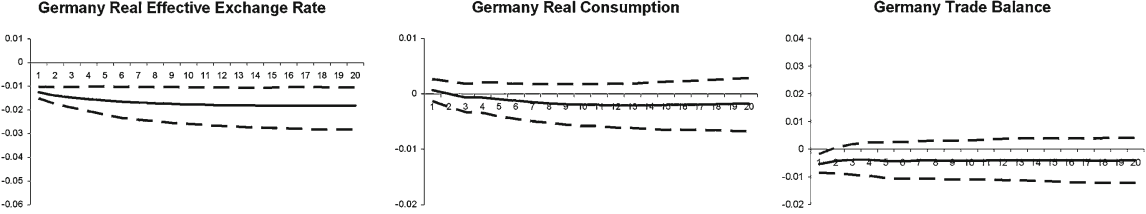

Japan Real Effective Exchange Rate
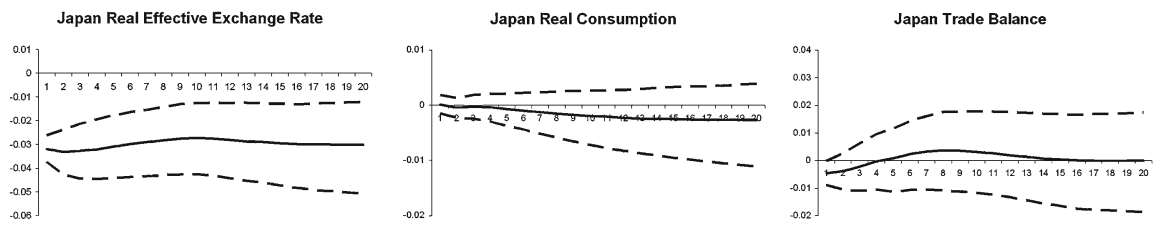

Fig. 1 Domestic response to a domestic negative real effective exchange rate shock, with consumption in the model. Real effective exchange rate (first column), real consumption (second column), and trade balance (third column)

all countries, but the magnitude differs, from an initial $-1 \%$ for France to an initial $-3 \%$ for Japan.

The exchange rate depreciation leads to a statistically significant fall in US real consumption (second column) of about $0.1 \%$ on impact and up to $0.4 \%$ after 20 quarters. Perhaps surprising, a significant effect is only observed for the US, which is in terms of trade/gdp ratio, together with Japan, the least open economy of the G5. Ex ante, we would expect more open economies to be affected more strongly by exchange rate movements.

Only the US trade balance shows a strong and significant response to a negative exchange rate shock (third column). Taken together, the finding of a decrease in consumption and improving trade balances contrasts with Goldberg and Tille (2006) and Gust and Sheets (2006). Both studies argue that exchange rate movements are largely 
passed through to the trade balance via exports, leaving US expenditure on imports relatively unchanged. Here, US demand appears to be an important determinant. We do not observe the initial J-curve effect, confirming previous studies, among others Rose and Yellen (1989).

For Germany and Japan, we find that the trade balance first significantly worsens by about $0.5 \%$ on impact, but returns to balance already after the first quarter. This result seems counterintuitive, because both Germany and Japan are large exporting nations and the demand for their export products should depend on the exchange rate. However, it is important to realize that about half of Germany's trade is with eurozone countries and a real exchange rate depreciation is quickly passed on to the other eurozone countries. ${ }^{11}$ Therefore, the effect on the trade balance may be quite limited, which confirms the findings of Lane and Milesi-Ferretti (2002). These authors also find a much weaker dependence of German, French, and UK trade balances on real exchange rate movements compared to the US.

Figure 2 presents the GIRFs for the model with consumption replaced by investment. The impulse responses of the real effective exchange rate are very similar to those in Fig. 2 for all countries. Again, only the US trade balance shows a strong improvement, but this vanishes after ten quarters. The US investment is only marginally significantly negative, so it is not obvious that the exchange rate shock is transmitted via investment to the trade balance.

For Japan and Germany, the trade balance is marginally negative during some part of the 20 quarter horizon. The magnitude is so small that we should be careful in drawing strong conclusions from these findings.

\subsection{Stock price shock}

Next, we expose domestic real stock prices to a one standard error negative shock in each of the G5 countries. The associated GIRFs for the model with consumption are shown in Fig. 3. The shock amounts to a drop in real stock prices of 4-6\% for all countries. For the US and Japan, the shock is very persistent and remains significantly negative even after 20 quarters. However, UK, French, and German stock prices become insignificant after a few quarters. This shows that these stock markets depend to a large extent on global events and local shocks are relatively short lived.

We find a strong response of consumption to the stock price shock for the US and UK. Real consumption falls by $0.1 \%$ on impact and stabilizes around $-0.7 \%$ after 20 quarters in both countries. For France and Japan, consumption is significantly negative during the first three quarters for France and from quarter 3 to 10 for Japan. There is no effect on German consumption. This is suggestive of the finding that the domestic wealth effect is less pronounced for countries with bank-based, in contrast to market-based, financial systems (Ludwig and Sløk 2004). These authors also show that French and German stock ownership is much lower compared to the US and UK, which is an important explanation for the observed smaller effect.

\footnotetext{
11 Even before the introduction of the euro in 1999 many European countries pegged their currency (or allowed exchange rate bands) to the German Mark under the European Exchange Rate Mechanism.
} 
US Real Effective Exchange Rate

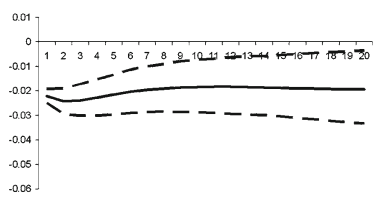

UK Real Effective Exchange Rate

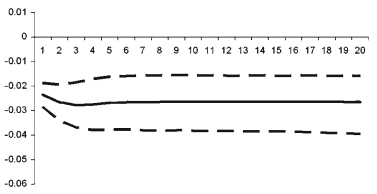

France Real Effective Exchange Rate

L2ー-7- -

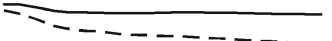

-0.03 .

$-0.05-$

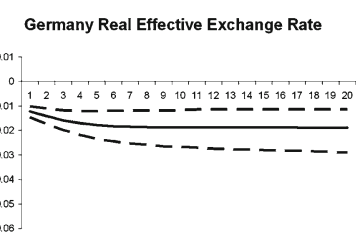

Japan Real Effective Exchange Rate

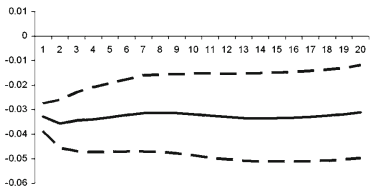

US Real Investment

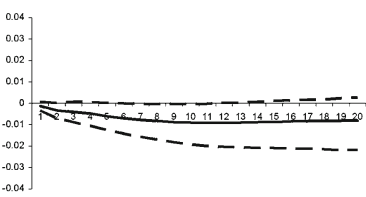

UK Real Investment

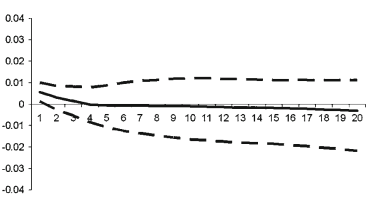

France Real Investment

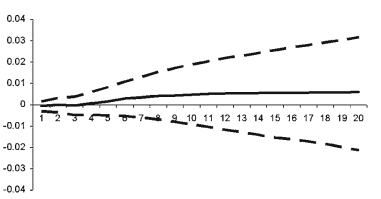

Germany Real Investment

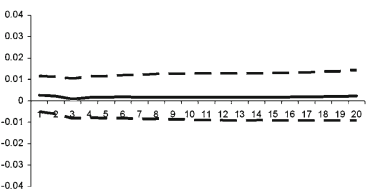

Japan Real Investment

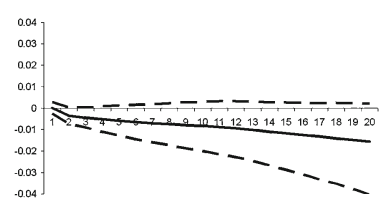

US Trade Balance

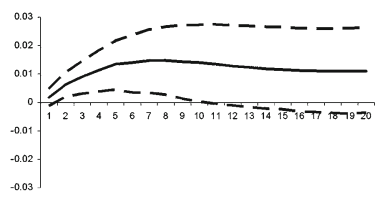

UK Trade Balance

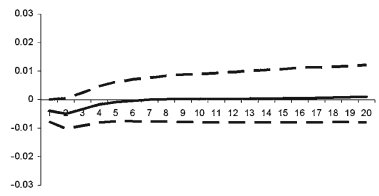

France Trade Balance

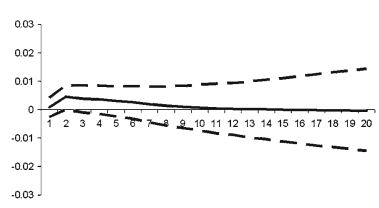

Germany Trade Balance

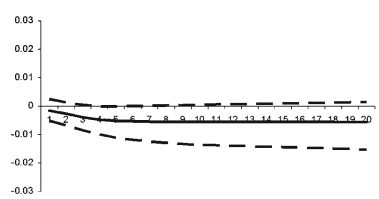

Japan Trade Balance

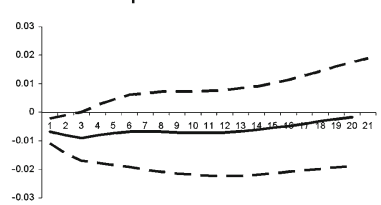

Fig. 2 Domestic response to a domestic negative real effective exchange rate shock, with investment in the model. Real effective exchange rate (first column), real investment (second column), and trade balance (third column)

The international wealth channel is at work in both the US and UK: for both countries, we document a significant improvement of the trade balance, in combination with decreasing stock prices and lower consumption. The dynamics differ slightly, i.e., for the US the trade balance is not significantly positive after the 12th quarter, whereas in the UK we find that the trade balance only becomes significantly positive after the sixth quarter and remains so thereafter. For France, we observe a small improvement, whereas the German and Japanese trade balances are unaffected. This suggests that the Japanese decrease in consumption is primarily a drop in consumption of domestic goods and not imported goods.

Figure 4 presents the GIRFs for the second model, where consumption is replaced by investment. Again, we consider a one standard deviation negative shock to domestic stock prices. Column 1 presents similar results for the stock price shock as shown 

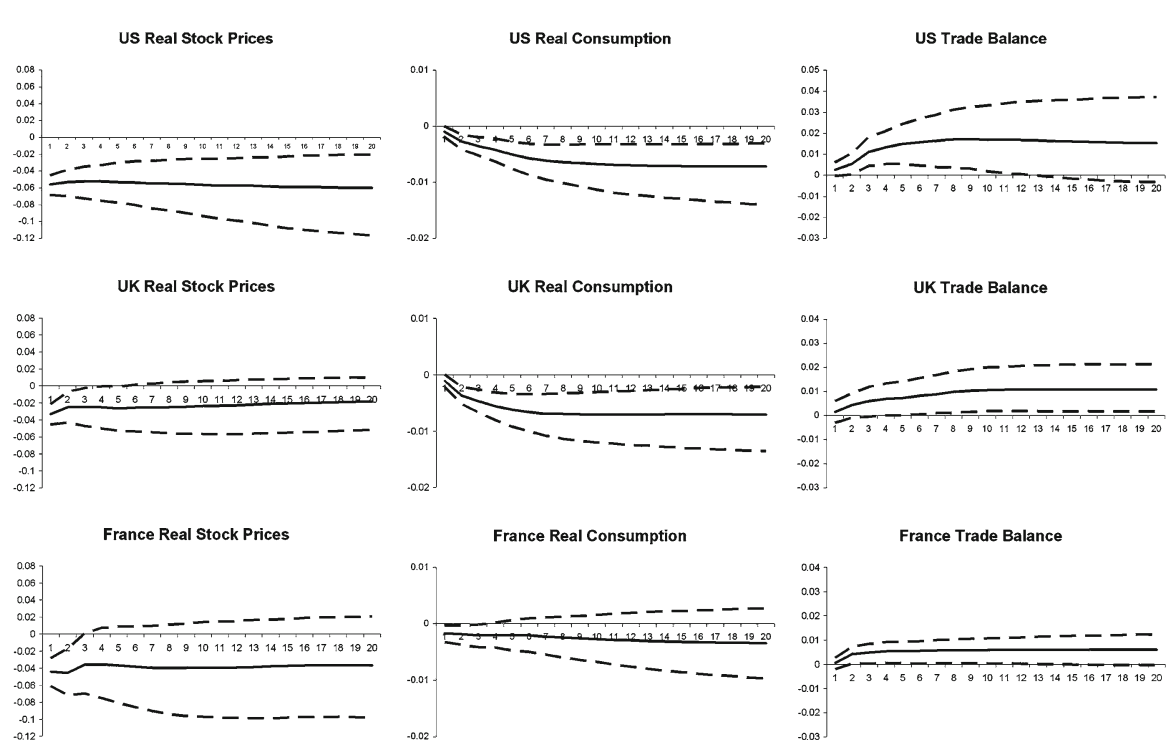

Germany Real Stock Prices

Germany Real Consumption
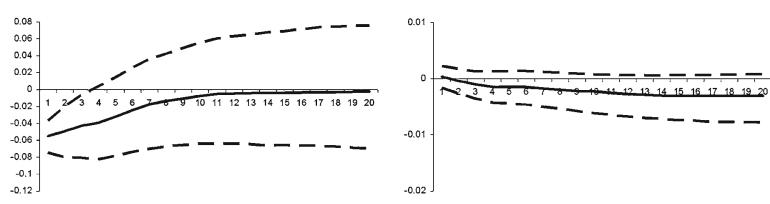

Germany Trade Balance

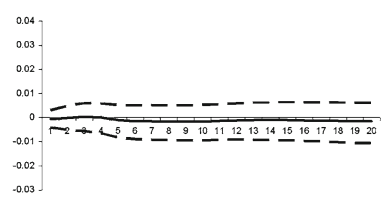

Japan Real Stock Prices

Japan Real Consumption

Japan Trade Balance
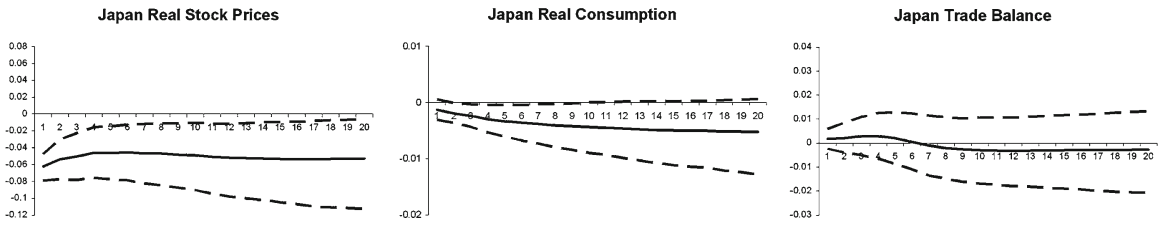

Fig. 3 Domestic response to a domestic negative real stock price shock, with consumption in the model. Real stock price (first column), real consumption (second column), and trade balance (third column)

in Fig. 3. US and Japanese stock prices remain negative over the predicted horizon, while the other countries' stock market returns become quickly insignificant. This is due to the leading role of the US stock market and relative isolation of Japan.

The GIRFs for real investment show broadly similar patterns as the GIRFs for real consumption. US investment is significantly negative as of the second quarter, while UK investments are only marginally significant during quarters $5-11$. French, German, and Japanese investment remains unaffected. One reason for the wider confidence bounds of investment compared to consumption is the higher volatility of investment. In fact, investment is among the most difficult economic variables to model and is known for its high prediction error in macroeconomic models. ${ }^{12}$

12 See e.g., Smets and Wouters (2003). 
US Real Stock Prices

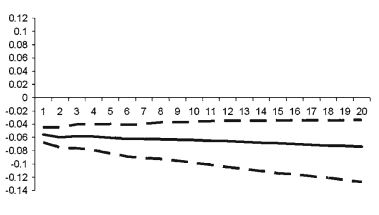

UK Real Stock Prices

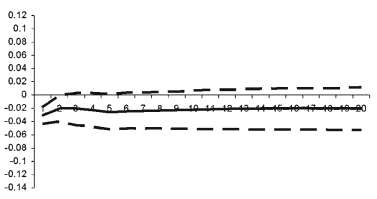

France Real Stock Prices

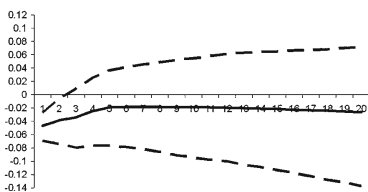

Germany Real Stock Prices

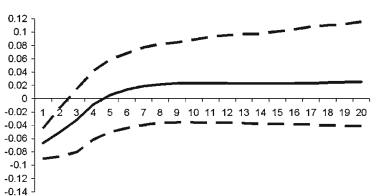

Japan Real Stock Prices

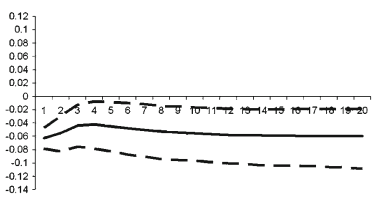

US Real Investment

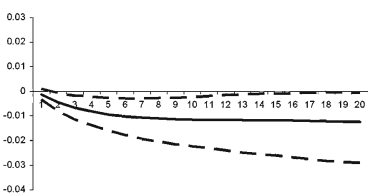

UK Real Investment

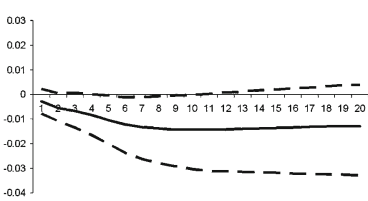

France Real Investment

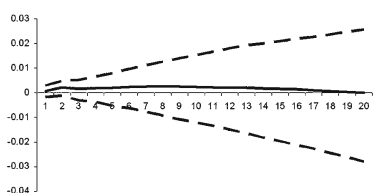

Germany Real Investment

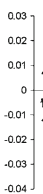

- -------

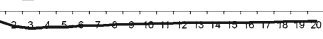

- - - - - - - - -

-

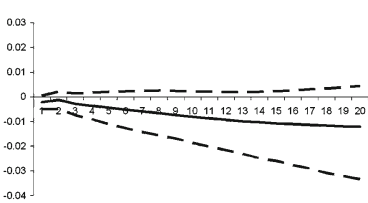

US Trade Balance

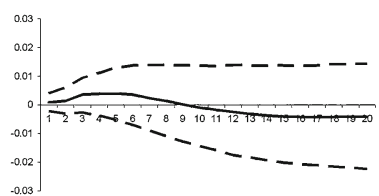

UK Trade Balance

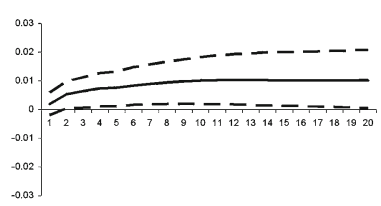

France Trade Balance

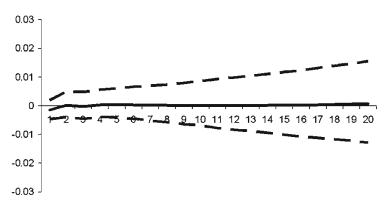

Germany Trade Balance

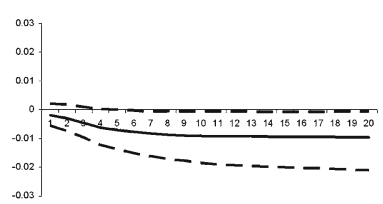

Japan Trade Balance

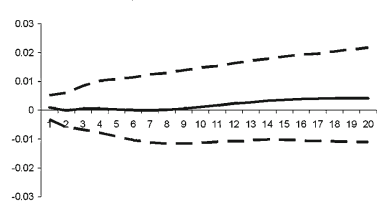

Fig. 4 Domestic response to a domestic negative real stock price shock, with investment in the model. Real stock price (first column), real consumption (second column), and trade balance (third column)

Only the UK trade balance improves significantly in response to a stock price shock. Hence, for the UK we find evidence, albeit weak, in favor of the international wealth channel through investment. For the other countries this channel does not seem to be present. On the other hand, the German trade balance become marginally significantly negative. There is no obvious explanation for this pattern.

\subsection{Housing price shock}

The final shock is a one standard deviation negative shock to domestic housing prices. Again, first consider the model with consumption, followed by the model with investment. Figure 5 shows the impulse response functions for the US, UK, and France. Housing price index data is not available for Germany and Japan. Column 1 shows the 


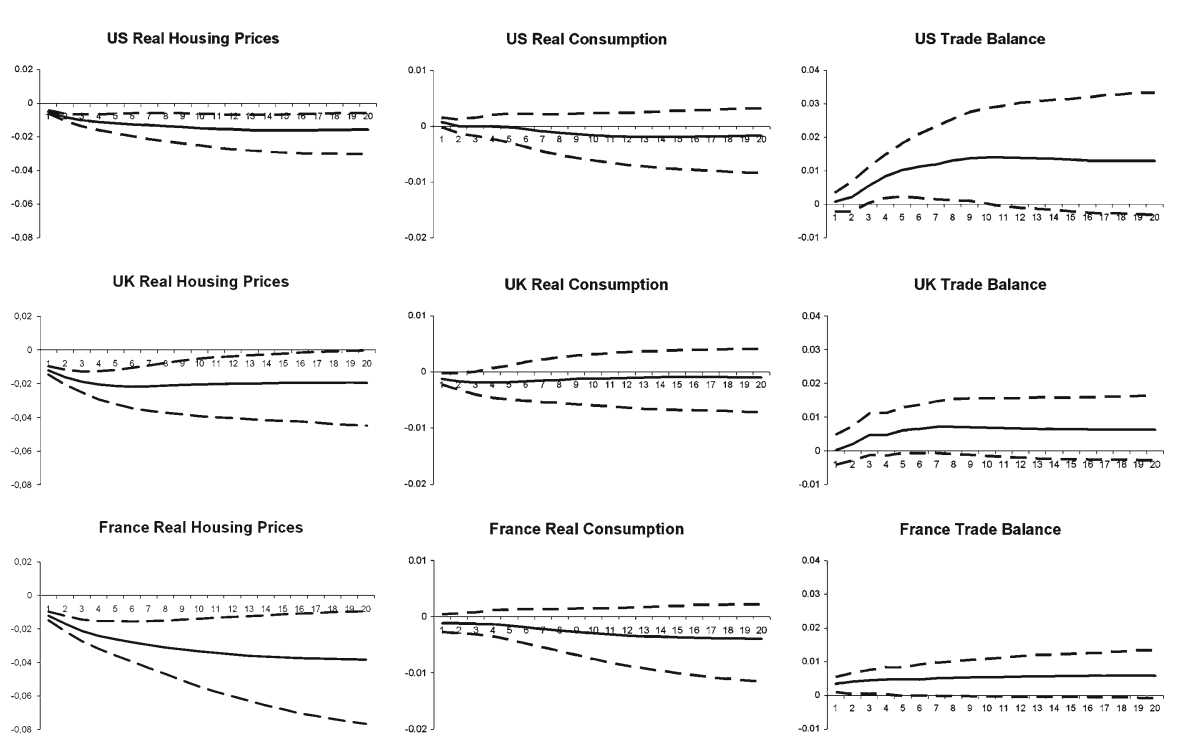

Fig. 5 Domestic response to a domestic negative real housing price shock, with consumption in the model. Real housing price (first column), real consumption (second column), and trade balance (third column)

magnitude of the housing shock, which is close to $-1 \%$ for all countries and increases to about $-2 \%$ for the US and UK and $-3 \%$ for France. These shocks are smaller than the stock market shocks, since housing prices are historically more stable than stock prices.

Column 2 shows that the point estimates of the reactions of consumption are negative but insignificant for all three countries. We only find a significantly negative reaction for the UK during the first three quarters. This small effect is surprising since most previous studies find that consumption reacts stronger to housing price shocks than stock price shocks (Case et al. 2005). It is even more surprising taking into account the less stringent collateral and downpayment constraints in the US and UK, facilitating consumption out of housing wealth (Muellbauer and Murphy 2008). However, note that the absolute magnitude of the housing price shock is smaller than the stock price shock, which explains part of the lower response.

US trade balance improves following the negative shock to the US real housing prices by up to $1.3 \%$ after 10 quarters. However, it is only statistically significant between quarters 1 and 10. There is no impact on the UK trade balance, while the French trade balance is marginally significantly positive during the first four quarters and insignificant thereafter. In sum, for the housing shock we find no evidence in favor of the international wealth channel.

Figure 6 displays the GIRFs of the model with investment included. The pattern of the real housing price shocks is similar to Fig. 5 for the US and UK, but differs for France. For the latter country, the shock becomes insignificant after nine quarters.

Following the housing price shock, only UK real investment responds significantly negative over the entire horizon. The US and French investment are never significantly different from zero. This is surprising, since there exists evidence of a strong 
US Real Housing Prices

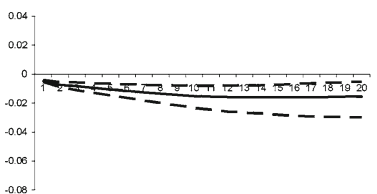

UK Real Housing Prices

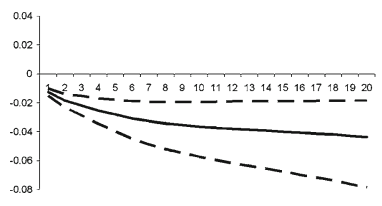

France Real Housing Prices

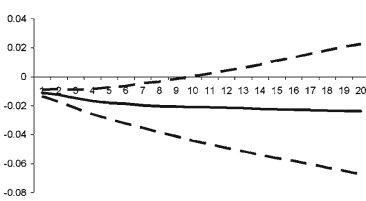

US Real Investment

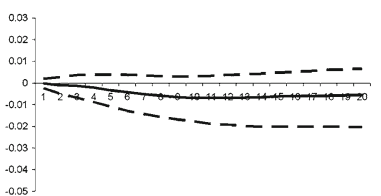

UK Real Investment

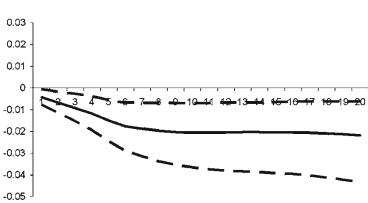

France Real Investment

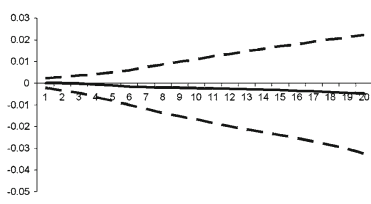

US Trade Balance

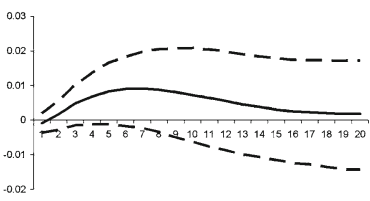

UK Trade Balance

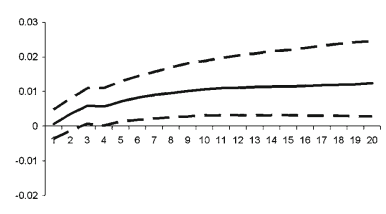

France Trade Balance

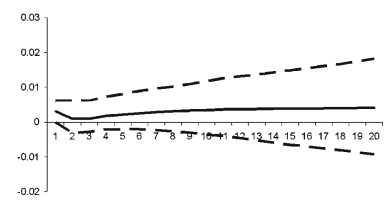

Fig. 6 Domestic response to a domestic negative real housing price shock, with investment in the model. Real housing price (first column), real consumption (second column), and trade balance (third column)

relationship between housing prices and housing investment (Iacoviello and Neri 2010). Hence, ex ante we would expect a negative effect for the US. With regard to the trade balance, again only the UK shows significant results, providing evidence for the existence of the international wealth channel through investment.

\section{Forecast error variance decomposition}

Complementary to the GIRF analysis in the previous section, we conduct a generalized forecast error variance decomposition (GFEVD) to answer the question of how much of the error variance in forecasting the trade balance can be attributed to shocks in the real effective exchange rate, real stock market, and real housing prices. Table 3 reports the median variance decomposition percentage, with the 5 and $95 \%$ bounds in brackets. These variance bounds are relatively wide and should be interpreted with caution. However, the variance decomposition can still provide an indication on the relative importance of each of the three shocks for the trade balance.

Initially, the percentage for which the trade balance shock explains its own variance is relatively high for all countries. However, it decreases sharply for the US, UK, and Japan in both models. It remains high for Germany in both models and for France only in the consumption model. A high percentage indicates that the trade balance is very persistent and relatively unaffected by shocks originating in other variables.

Next, we compare the explanatory power of the three shocks in the consumption model. The medians for all shocks are highest for the US. When comparing the relative importance of each of the three shocks for the US, while taking into account the confidence bounds, we can conclude that all shocks are about equally important. Hence, asset price shocks explain a meaningful part of US trade balance developments. 


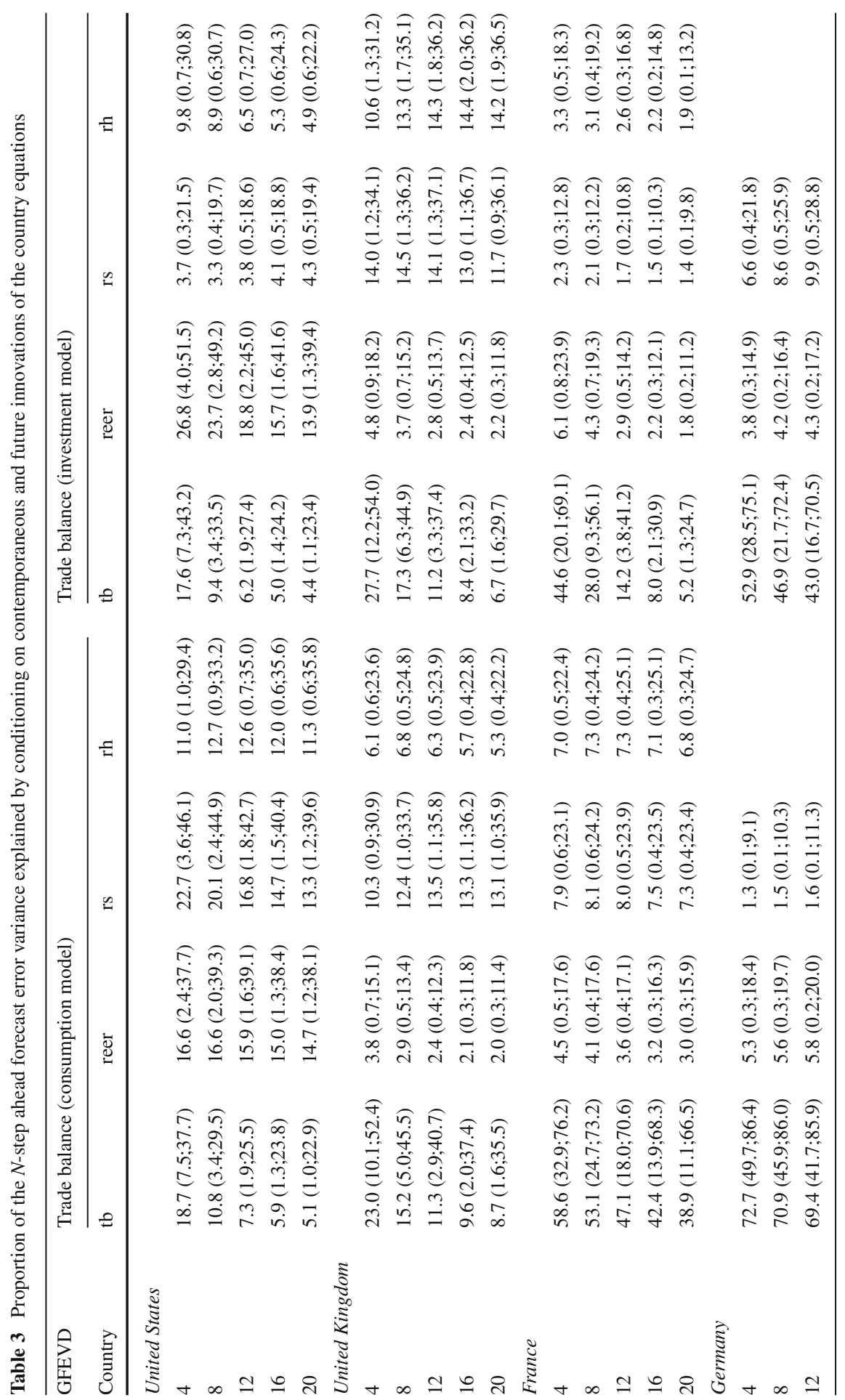




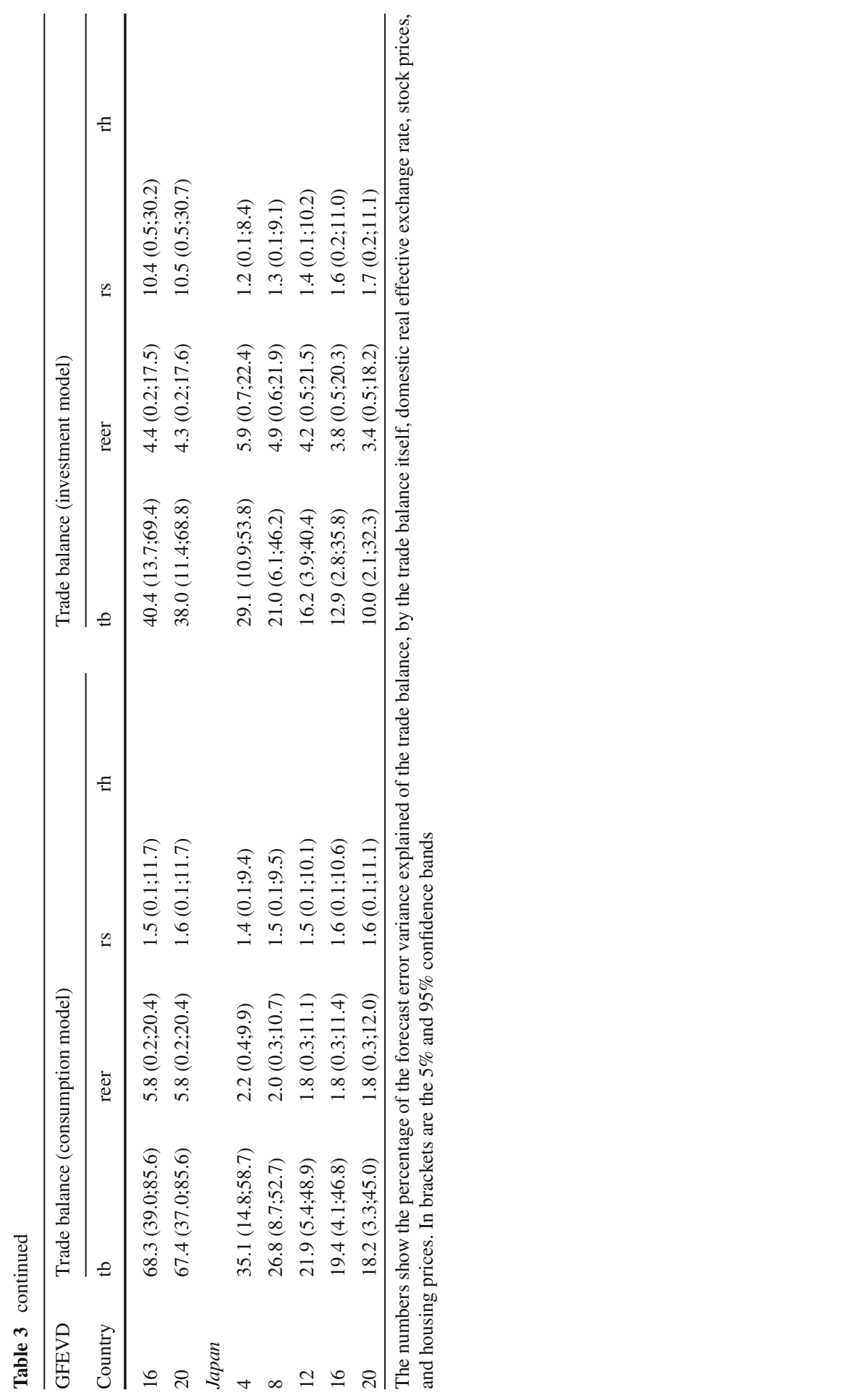


For the UK and France, we find that the median percentages of stock and housing price shocks are higher than the exchange rate shock. On the other hand, for Germany the exchange rate shock appears to be more important, while for Japan both shocks explain only a very small percentage of the trade balance. In sum, asset price shocks are important for the trade balance in the consumption model, but their importance differs across countries.

Next, turning to the investment model, the picture is slightly altered. The trade balance explains a smaller percentage of its own variance, with the decrease being most pronounced in France and Germany. Interestingly, the three shocks show a different picture across countries. In the US, the median percentage of the exchange rate is more than the sum of the stock and housing price shocks. Hence, when replacing consumption with investment in the model, asset price shocks appear to be less important for the US trade balance. Therefore, the international wealth channel is strongest when using the consumption channel for the US.

The UK figures are broadly similar to the consumption model, with the role of housing shocks being slightly more important. For France, asset price shocks are less important, while in Germany their importance increases. In Japan, the exchange rate appears to explain more of the variation. So, these results indicate that is important to distinguish between modeling the international wealth channel via consumption or investment and that the impact of asset price shocks on the trade balance differs across countries, thereby supporting the results of the GIRFs presented earlier.

\section{Conclusion}

In this article, we empirically test for the presence of the international wealth channel: asset price shocks are transmitted to the trade balance through consumption and investment. In particular, we test if it is a potential alternative to exchange rate changes in explaining trade balance movements using the GVAR model developed by Pesaran et al. (2004) and Dees et al. (2007). It proceeds in two steps. First, we estimate individual country VECMs for 29 countries over the period 1981Q1-2006Q4. Second, we combine these country-individual models into a global VAR representation using information on bilateral trade patterns. In particular, to study the role of the consumption and investment channel, we estimate one GVAR model with consumption included, while in the second consumption is replaced by investment.

Using generalized impulse response functions three domestic negative shocks are analyzed for the US, UK, France, Germany, and Japan: (1) real exchange rate, (2) real stock price, and (3) real housing price. These results provide evidence in favor of the existence of the international wealth channel. First, real exchange rate shocks only seem to impact US developments in consumption and the trade balance. Second, a negative shock to real stock prices is associated with a significant decrease in consumption and an improvement in the trade balance in the US, UK, and to a weaker extent in France. When considering the model with investment, we only find weak evidence for the presence of the international wealth channel for the UK. Finally, a negative housing price shock only weakly affects consumption in the UK, without an effect on the trade balance. On the other hand, in the investment model, the negative housing 
price shock is associated with a significant decrease in investment and significantly improving trade balance in the UK.

In sum, the international wealth channel is an important alternative explanation of trade balance movements. However, the results cannot be generalized to all countries. The empirical methodology is suitable to explain trade balance behavior during relatively stable periods. Unfortunately, the model is less suitable to study trade balances during crisis periods. Further research is needed to study the working of the international wealth channel during the current global financial crisis. We believe this to be a promising future research avenue.

Acknowledgments The authors thank seminar participants at Trinity College Dublin, STATEC Luxembourg, DIW Macroeconometric Workshop Berlin, EEFS Conference Warsaw, INFINITI Conference Dublin, and NAKE Research Day Utrecht for useful comments. They also thank Michel Beine, Bertrand Candelon, Clemens Kool, Ayhan Kose, Joan Muysken, Jean-Pierre Urbain, and two anonymous referees for constructive comments and discussions. The second author gratefully acknowledges support by the Fonds National de Recherche Luxembourg under grant FNR/VIVRE/06/30/10. Views expressed in this article do not necessarily coincide with those of De Nederlandsche Bank. All errors are our own.

Open Access This article is distributed under the terms of the Creative Commons Attribution Noncommercial License which permits any noncommercial use, distribution, and reproduction in any medium, provided the original author(s) and source are credited.

\section{Appendix}

\section{Data sources}

- Trade data for all countries are from the IMF Direction of Trade Statistics at the quarterly frequency and in US\$. The trade balance is constructed as the log of exports over imports and seasonally adjusted in EViews using the X12 method of the US Census Bureau.

- Nominal consumption, investment, output and inflation data are from the IMF International Financial Statistics at the quarterly frequency an in domestic currency. For China, India, Indonesia, Malaysia, New Zealand, Saudi Arabia, and Thailand annual data are interpolated to a quarterly frequency in some cases. We interpolate the data by first taking logs and assuming a constant growth rate between two annual observations. Real consumption and real output are seasonally adjusted in EViews using the X12 method of the US Census Bureau.

- Real effective exchange rate data are taken from the IMF International Financial Statistics at the quarterly frequency.

- Stock price data are from Global Financial Data using a large domestic stock market index. Stock market index prices are denominated in local currencies and at the quarterly frequency.

- United States (S\&P 500 Composite Price Index), Japan (Nikkei 225 Stock Average), and India (Bombay SE Sensitive Index)

- European countries: Austria (Wiener Boersekammer Share Index), Belgium (Brussels All-Share Price Index), Denmark (OMX Copenhagen All-Share Price Index), Finland (OMX Helsinki All-Share Price Index), France (SBF-250 
Index), Germany (CDAX Composite Index), Italy (Banca Commerciale Italiana Index), Luxembourg (LuXX Index), Netherlands (All-Share Price Index), Norway (Oslo SE All-Share Index), Spain (Madrid SE General Index), Sweden (Affarsvarlden General Index), and United Kingdom (FTSE All-Share Index)

- Other OECD: Australia (ASX All-Ordinaries), Canada (S\&P/TSX 300 Composite), Mexico (SE Indice de Precios y Cotizaciones), and New Zealand (SE Share Capital All Index)

- South-East Asia: Korea (SE Stock Price Index KOSPI), Malaysia (KLSE Composite), Philippines (Manila SE Composite Index), Singapore (FTSE AllShare Index), and Thailand (SET General Index)

- Housing price data are from the Bank for International Settlements at quarterly frequency.

- Both short term and long term interest rates are from the IMF International Financial Statistics at the quarterly frequency.

- The oil price is the price in US\$ of one barrel Brent crude and retrieved through Datastream.

\section{References}

Barro RJ (1990) The stock market and investment. Rev Financ Stud 3(1):115-131

Beaudry P, Portier F (2006) Stock prices, news and economic fluctuations. Am Econ Rev 96(4):1293-1307

Bems R, Dedola L, Smets F (2007) US imbalances: the role of technology and policy. J Int Money Financ 26(4):523-545

Bergvall A (2004) What determines real exchange rates? The Nordic countries. Scand J Econ 106(2):315337

Black A, Hoesli P, Fraser M (2006) House prices, fundamentals and bubbles. J Bus Financ Acc 33(9 \& 10):1535-1555

Blanchard O, Giavazzi F, Sa F (2005) The U.S. current account and the dollar. Brookings Pap Econ Activ $1: 1-65$

Caballero R, Farhi E, Gourinchas PO (2008) An equilibrium model of "global imbalances" and low interest rates. Am Econ Rev 98(1):358-393

Case KE, Shiller RJ (2003) Is there a bubble in the housing market? Brookings Pap Econ Activ 2:299-362

Case KE, Quigley JM, Shiller RJ (2005) Comparing wealth effects: the stock market versus the housing market. Adv Macroecon 5(1):1-32

Corsetti G, Dedola L, Leduc S (2008) Productivity, external balance and exchange rates: evidence on the transmission mechanism among G7 countries. Rev Econ Stud 75:443-473

Dees S, Di Mauro F, Pesaran MH, Smith LV (2007) Exploring the international linkages of the euro area: a global VAR analysis. J Appl Econom 22:1-38

Fratzscher M, Straub R (2009) Asset prices and current account fluctuations in G7 economies. IMF Staff Pap 56(3):633-654

Fratzscher M, Juvenal L, Sarno L (2010) Asset prices, exchange rates and the current account. Eur Econ Rev 54:643-658

Friedman M (1957) A theory of the consumption function. Princeton University Press, Princeton, NJ

Galesi A, Sgherri S (2009) Regional financial spillovers across europe: a global var analysis. IMF Working paper 09/23, International Monetary Fund

Goldberg L, Tille C (2006) The internationalization of the dollar and trade balance adjustment. Federal Reserve Bank of New York Staff Report 255

Green RK, Malpezzi S, Mayo SK (2005) Metropolitan-specific estimates of the price elasticity of supply of housing, and their sources. Am Econ Rev 95(2):334-339 
Gust C, Sheets N (2006) The adjustment of global external imbalances: does partial exchange rate passthrough to trade prices matter? Federal Reserve Bank International Finance Discussion Papers No. 855

Iacoviello M, Neri S (2010) Housing market spillovers: evidence from an estimated DSGE model. Am Econ J Macroeconom 2(2):125-164

Kasa K (1992) Common stochastic trends in international stock markets. J Monet Econ 29:95-124

Koop G, Pesaran MH, Potter SM (1996) Impulse response analysis in nonlinear multivariate models. J Econom 74:119-147

Laibson D, Mollerstrom J (2010) Capital flows, consumption booms and asset bubbles: a behavioural alternative to the savings glut hypothesis. Econ J 120(May):354-374

Lane P, Milesi-Ferretti GM (2002) External wealth, the trade balance, and the real exchange rate. Eur Econ Rev 46:1049-1071

Lane P, Milesi-Ferretti GM (2008) International investment patterns. Rev Econ Stat 90(3):538-549

Lettau M, Ludvigson S (2001) Consumption, aggregate wealth, and stock returns. J Financ 56(3):815-849

Lettau M, Ludvigson S (2004) Understanding trend and cycle in asset values: reevaluating the wealth effect on consumption. Am Econ Rev 94(1):276-299

Ludvigson S, Steindel C (1999) How important is the stock market effect on consumption. Fed Reserve Bank N Y Econ Policy Rev 5(2):29-51

Ludwig A, Sløk T (2004) The relationship between stock prices, house prices and consumption in OECD countries. Top Macroecon 4(1, Article 4):1-26

Meese R, Rogoff K (1988) Was it real? The exchange rate-interest differential over the modern floating-rate period. J Financ 43(4):933-948

Modigliani F, Brumberg R (1954) Utility analysis and the consumption function: an interpretation of crosssection data. Rutgers University Press, New Brunswick

Muellbauer J, Murphy A (2008) Housing markets and the economy: the assessment. Oxf Rev Econ Policy 24(1):1-33

Obstfeld M, Rogoff K (1996) Foundations of international macroeconomics. The MIT Press, Cambridge, MA

Palumbo M, Rudd J, Whelan K (2006) On the relationships between real consumption, income, and wealth. J Bus Econ Stat 24(1):1-11

Pesaran MH, Shin Y (1998) Generalized impulse response analysis in linear multivariate models. Econ Lett 58:17-29

Pesaran MH, Schuermann T, Weiner SM (2004) Modeling regional interdependencies using a global errorcorrecting macroeconometric model. J Bus Econ Stat 22(2):129-162

Portes R, Rey H (2005) The determinants of cross-border equity flows. J Int Econ 65:269-296

Punzi MT (2008) Housing market and current account imbalances in the international economy. Mimeo, Boston College

Richards A (1995) Comovements in national stock market returns: evidence of predictability, but not cointegration. J Monet Econ 36:631-654

Rose AK, Yellen JL (1989) Is there a J-curve. J Monet Econ 24:53-68

Smets F, Wouters R (2003) An estimated dynamic stochastic general equilibrium model of the euro area. J Eur Econ Assoc 1(5):1123-1175

Sørensen PB, Whitta-Jacobsen HJ (2005) Introducing advanced macroeconomics: growth \& business cycles. Mc Graw Hill, Maidenhead

Tobin J (1969) A general equilibrium approach to monetary theory. J Money Credit Bank 1:15-29 